\title{
Effects of feeding triticale dried distillers grains plus solubles as a nitrogen source on productivity of lactating dairy cows
}

\author{
M. Oba, ${ }^{1}$ G. B. Penner, T. D. Whyte, and K. Wierenga \\ Department of Agricultural, Food and Nutritional Science, University of Alberta, Edmonton, AB, Canada, T6G 2P5
}

\begin{abstract}
The objective of this study was to compare triticale dried distillers grains plus solubles (TDDGS) as a source of dietary $\mathrm{N}$ with other high-protein feeds commonly used in North America: corn dried distillers grains plus solubles (CDDGS), canola meal (CM), and soybean meal $(\mathrm{SBM})$. Rumen degradable protein (\% of crude protein, CP) after $16 \mathrm{~h}$ of incubation in the rumen was higher for CDDGS and TDDGS (69.3\% and $64.5 \%$, respectively) than for CM $(62.2 \%)$ and SBM (53.0\%). For the lactation study, experimental diets were formulated to supply $30 \%$ of dietary CP from TDDGS, CDDGS, CM, or SBM. These diets contained $22.3 \%$ forage neutral detergent fiber and approximately $19.2 \% \mathrm{CP}$ and were fed to 12 multiparous Holstein cows $(130 \pm 40 \mathrm{~d}$ in milk) in a $4 \times 12$ Latin rectangle design with 21-d periods. Neither dry matter intake nor milk yield was affected by treatment, averaging 25.5 and $35.5 \mathrm{~kg} / \mathrm{d}$, respectively. Plasma concentrations of Arg, Lys, and Thr were greater for cows fed CM or SBM compared with those fed TDDGS or CDDGS, whereas plasma concentrations of Leu and Phe were lower for cows fed CM or SBM compared with those fed TDDGS or CDDGS. Cows fed CDDGS had lower milk $\mathrm{CP}$ yield compared with cows fed CM (1.07 vs. 1.16 $\mathrm{kg} / \mathrm{d}$ ). Contrarily, milk CP and milk lactose yields were not different for cows fed TDDGS compared with CM or SBM. These data suggest that TDDGS can replace $\mathrm{CM}$ or SBM in the diets of lactating dairy cows without adverse effects on production. Furthermore, although dried distillers grain has been generally accepted as a feed high in ruminal undegradable protein, CDDGS and TDDGS used in the present study had high in situ ruminal degradable crude protein. Further investigation is warranted to determine the extent of variation in ruminal protein degradation among different types of dried distillers grains.
\end{abstract}

Received June 4, 2009.

Accepted January 15, 2010.

${ }^{1}$ Corresponding author: moba@ualberta.ca
Key words: triticale, dried distillers grains plus solubles, dairy cow, milk production

\section{INTRODUCTION}

Dried distillers grains plus solubles (DDGS) has been used as a nitrogen source in diets for lactating dairy cows. The nutritional quality of corn DDGS (CDDGS) has been well documented in the literature, and effects of feeding CDDGS on productivity of dairy cows relative to soybean meal (SBM) have been studied extensively. Low degradability in the rumen (Firkins et al., 1984), risk of heat-damaged protein (Van Horn et al., 1985), fiber with lower physical effectiveness (Clark and Armentano, 1997), high fat content (Leonardi et al., 2005), and low Lys content (Kleinschmit et al., 2006) have been identified as the nutritional characteristics of CDDGS that could affect productivity of dairy cows.

Although corn grain has been used as the primary substrate for ethanol production in North America, other cereal grains are also suitable for ethanol production depending on cost and availability. Triticale, a cross between wheat and rye, was recognized as an alternative cereal grain for the fuel ethanol industry, especially in areas where corn cannot be grown (Wang et al., 1997). Distillers grains derived from triticale were shown to have similar ruminal degradability to those derived from wheat and rye (Mustafa et al., 2000) and slightly higher lysine content compared with CDDGS (Greter et al., 2008). Replacing CDDGS with triticale DDGS (TDDGS) did not result in any negative effects on productivity of lactating dairy cows (Greter et al., 2008). However, to the authors' knowledge, the feeding value of TDDGS has not been compared with that of SBM or canola meal (CM), the most common protein sources for lactating dairy cows in North America. Furthermore, few data are currently available in the literature to characterize ruminal degradability and intestinal digestibility of TDDGS to optimize its utilization.

Therefore, the objectives of this study were to estimate ruminal and intestinal digestibility of TDDGS, CDDGS, CM, and SBM, and to compare the effects 
of feeding these feeds as the primary dietary protein source on productivity of lactating dairy cows.

\section{MATERIALS AND METHODS}

\section{In Situ Study}

Three multiparous lactating Holstein dairy cows (DIM $273 \pm 60$ ) were used to determine ruminal CP disappearance of TDDGS, CDDGS, CM, and SBM used in the lactation study. All protein feeds evaluated in this study were sourced in Alberta, Canada. The TDDGS and CDDGS were made exclusively from corn and triticale, respectively, and both were processed under similar conditions at a local whiskey distillery (Alberta Distillers, Calgary, AB, Canada). Samples were analyzed for AA composition by Degussa (Hanau, Germany) according to the method described by Kim et al. (2006; Table 1). In situ bags $(5 \times 10 \mathrm{~cm}, 50 \mu \mathrm{m}$ pore size, Ankom Technology, Macedon, NY) containing 2-g samples were prepared in triplicate for each cow and each time point described below. All samples were soaked for $15 \mathrm{~min}$ in warm water $\left(38^{\circ} \mathrm{C}\right)$ and incubated in the rumen for $0,1,2,4,8,16,24,48$, and $72 \mathrm{~h}$. After ruminal incubation, the bags were rinsed with tap water until the rinse water was clear, then frozen overnight, thawed, and rinsed again to remove microbes attached to feed particles. The residues were subsequently analyzed for concentration of CP (AOAC, 2000; method 990.03) using a Leco analyzer (Leco FP2000 N Analyzer, Leco Instruments Inc., St. Joseph, $\mathrm{MI})$. Soluble $\mathrm{CP}$ was defined as the $\mathrm{CP}$ that disappeared at time 0 , rapidly degradable $\mathrm{CP}$ was defined as $\mathrm{CP}$ disappeared within $1 \mathrm{~h}$ of ruminal incubation, and indigestible $\mathrm{CP}$ was defined as $\mathrm{CP}$ residues after $72 \mathrm{~h}$ of ruminal incubation; slowly degradable $\mathrm{CP}$ was calculated by subtracting soluble $\mathrm{CP}$, rapidly degradable CP, and indigestible CP from 100. Degradable CP fraction of feeds was separated into slowly and rapidly degradable fractions for this study because the rate of $\mathrm{CP}$ disappearance for the degradable $\mathrm{CP}$, as calculated according to Dairy NRC (2001), did not follow the first-order kinetics for the DDGS samples evaluated in this study. As such, rate of CP disappearance was calculated for slowly degradable $\mathrm{CP}$ using the equation

$$
\mathrm{R}_{t}=\mathrm{R}_{0} \times \mathrm{e}^{-\mathrm{k} t}
$$

where $\mathrm{R}_{t}=$ residue at time $t, \mathrm{R}_{0}=$ residue at time $0, t=$ time of ruminal incubation, $\mathrm{k}=$ rate of disappearance. The RDP content was defined as CP that disappeared during the $16-\mathrm{h}$ incubation in the rumen. In addition, AA composition was analyzed for the 16-h incubation residues as described previously.
The in vitro intestinal digestibility of $\mathrm{CP}$ was determined according to Calsamiglia and Stern (1995) with minor modifications. After 16-h of ruminal incubation, each nylon bag was placed in a $50-\mathrm{mL}$ centrifuge tube, and $10 \mathrm{~mL}$ of $0.1 \mathrm{~N} \mathrm{HCl}$ solution $(\mathrm{pH} 1.9)$ with pepsin was added to each tube, vortexed, and incubated for 1 $\mathrm{h}$ in a shaking water bath (Julabo SW 22, Labortechniek, Seelbach, Germany) at $38^{\circ} \mathrm{C}$. Then, $0.5 \mathrm{~mL}$ of a 1 $N \mathrm{NaOH}$ solution and $13.5 \mathrm{~mL}$ of pancreatin solution were added, vortexed, and placed in a shaking water bath at $38^{\circ} \mathrm{C}$ for $24 \mathrm{~h}$. Samples were vortexed every 8 $\mathrm{h}$ during incubation. At the end of in vitro incubation, $3 \mathrm{~mL}$ of $100 \%$ (wt/vol) TCA solution was added to stop enzymatic reactions and to precipitate undigested protein. The bags were then rinsed in cool water, and the residues were analyzed for concentration of $\mathrm{CP}$ as described previously to determine in vitro intestinal digestibility.

\section{Lactation Study}

Twelve multiparous Holsteins cows in early to mid lactation (130 \pm 40 DIM; mean \pm SD) from the University of Alberta Dairy Research and Technology Centre (Edmonton, AB, Canada) were randomly assigned to a $4 \times 12$ Latin rectangle (Mead et al., 2003) balanced for carryover effects. At the beginning of the experiment, cows averaged $644 \pm 68 \mathrm{~kg}$ and BCS was 2.8 \pm 0.2 . Treatment periods were $21 \mathrm{~d}$, with the final 3 d used to collect samples and data. Cows were cared for according to guidelines of the Canadian Council on Animal Care (1993; Institutional Animal Use Approval Number: OBA-2006-57).

Four experimental diets were formulated to provide $30 \%$ of dietary CP from TDDGS, CDDGS, CM, or SBM (Table 2). The experimental diets contained different amounts of beet pulp and urea in an effort to make the diets isonitrogenous. All diets contained equal proportions of barley silage, alfalfa hay, dry ground corn, dry rolled barley, and minerals and vitamins (DM basis). Throughout the experiment, cows were housed in tie stalls with continuous access to water and were allowed to exercise for $2 \mathrm{~h}$ daily. Experimental diets were offered ad libitum ( $110 \%$ of expected intake) as a TMR once daily at $0900 \mathrm{~h}$, and cows were milked in their stalls at 0600 and $1700 \mathrm{~h}$.

Data and Sample Collection. Body weight was recorded on 2 consecutive days immediately before the start of the first period and on the last $2 \mathrm{~d}$ of each period. Body condition score was determined by a trained investigator at the beginning of the experiment and at the end of each period (a 5 -point scale was used, with 1 $=$ thin and $5=$ fat; Wildman et al., 1982). The amount of feed offered and orts were weighed and recorded daily. 
Table 1. Crude protein concentration and AA profile of triticale dried distillers grains plus solubles (TDDGS), corn dried distillers grains plus solubles (CDDGS), canola meal (CM), and soybean meal (SBM)

\begin{tabular}{|c|c|c|c|c|}
\hline Item & TDDGS & CDDGS & $\mathrm{CM}$ & SBM \\
\hline $\mathrm{DM}, \%$ & 89.4 & 88.1 & 90.1 & 91.0 \\
\hline $\mathrm{OM}, \%$ of $\mathrm{DM}$ & 96.0 & 96.3 & 91.1 & 92.4 \\
\hline NDF, \% of DM & 35.6 & 37.2 & 25.8 & 8.8 \\
\hline Ether extract, $\%$ of DM & 7.7 & 7.2 & 3.9 & 1.1 \\
\hline $\mathrm{CP}, \%$ of $\mathrm{DM}$ & 31.1 & 30.1 & 39.9 & 51.4 \\
\hline \multicolumn{5}{|l|}{$\mathrm{AA}, \%$ of $\mathrm{CP}$} \\
\hline Arginine & 4.26 & 4.07 & 6.17 & 7.23 \\
\hline Histidine & 2.57 & 2.55 & 2.69 & 2.58 \\
\hline Isoleucine & 3.46 & 3.43 & 4.01 & 4.59 \\
\hline Leucine & 8.80 & 8.64 & 7.19 & 7.81 \\
\hline Lysine & 2.08 & 1.86 & 5.65 & 6.42 \\
\hline Methionine & 1.80 & 1.72 & 2.06 & 1.41 \\
\hline Phenylalanine & 4.56 & 4.56 & 3.98 & 4.96 \\
\hline Threonine & 3.52 & 3.58 & 4.45 & 4.04 \\
\hline Valine & 4.47 & 4.50 & 5.05 & 4.76 \\
\hline Alanine & 5.62 & 5.66 & 4.53 & 4.46 \\
\hline Aspartate & 5.92 & 5.99 & 7.35 & 11.5 \\
\hline Cystine & 1.82 & 1.82 & 2.33 & 1.43 \\
\hline Glutamate & 20.4 & 19.3 & 17.8 & 18.2 \\
\hline Glycine & 3.88 & 3.92 & 5.13 & 4.34 \\
\hline Proline & 8.42 & 8.65 & 5.74 & 4.81 \\
\hline Serine & 4.56 & 4.52 & 4.39 & 5.09 \\
\hline \multicolumn{5}{|l|}{$\mathrm{AA},{ }^{1} \%$ of RUP } \\
\hline Arginine & 4.36 & 4.07 & 5.63 & 6.71 \\
\hline Histidine & 2.36 & 2.36 & 2.46 & 2.74 \\
\hline Isoleucine & 4.00 & 3.98 & 4.50 & 5.00 \\
\hline Leucine & 12.0 & 12.5 & 7.33 & 8.37 \\
\hline Lysine & 2.51 & 2.21 & 5.42 & 6.14 \\
\hline Methionine & 2.13 & 2.02 & 1.92 & 1.52 \\
\hline Phenylalanine & 5.07 & 5.17 & 4.46 & 5.18 \\
\hline Threonine & 3.61 & 3.61 & 4.83 & 4.28 \\
\hline Valine & 5.05 & 5.03 & 5.71 & 5.42 \\
\hline Alanine & 6.49 & 7.17 & 4.66 & 4.81 \\
\hline Aspartate & 6.99 & 6.39 & 8.00 & 11.4 \\
\hline Cystine & 1.93 & 1.95 & 1.91 & 1.63 \\
\hline Glutamate & 18.3 & 18.0 & 13.2 & 16.2 \\
\hline Glycine & 3.72 & 3.66 & 5.06 & 4.49 \\
\hline Proline & 6.67 & 7.17 & 5.01 & 4.40 \\
\hline Serine & 4.70 & 3.66 & 4.60 & 5.23 \\
\hline
\end{tabular}

${ }^{1} \mathrm{CP}$ residues after 16 -h in situ incubation in the rumen of lactating dairy cows.

Representative samples of all dietary ingredients and orts (approximately $12.5 \%$, as-fed basis) were collected daily during each collection period. Orts samples were pooled and one sample was retained per cow in each period. The DM content of barley silage and alfalfa hay was determined weekly to adjust dietary allocation of forages to maintain a consistent forage-to-concentrate ratio. Milk yield was measured daily and averaged over the 3 -d collection period. Milk was sampled at both a.m. and p.m. milkings on d 19, 20, and 21 of each period. Milk component concentrations (weighed by yield at each milking daily) and yields were averaged for each cow and period.

Fecal and blood samples were collected every $9 \mathrm{~h}$ from each cow on d 19 to 21 to account for diurnal variation. Fecal samples $(100 \mathrm{~g})$ were collected from the rectum, stored at $-20^{\circ} \mathrm{C}$, and composited into one sample per cow per period immediately before drying in a forcedair oven at $55^{\circ} \mathrm{C}$ for $72 \mathrm{~h}$. Blood was sampled from the coccygeal vessels using Vacutainer tubes containing sodium heparin (Becton Dickinson, Franklin Lakes, $\mathrm{NJ}$ ). Blood samples were immediately placed on ice and centrifuged within $1 \mathrm{~h}$ at $4^{\circ} \mathrm{C}$ for 20 min at 3,000 $\times g$. Plasma was harvested and frozen at $-20^{\circ} \mathrm{C}$ and composited into one sample per cow per period before further analysis.

Sample Analysis. Diet ingredients, orts, and feces were dried in a $55^{\circ} \mathrm{C}$ forced-air oven for $72 \mathrm{~h}$ to determine DM concentration. The dried samples were ground through a 1-mm screen using a Wiley mill (ThomasWiley, Philadelphia, PA). Samples were analyzed for concentrations of DM, ash, NDF, indigestible NDF, $\mathrm{CP}$, ether extract, and starch. Dry matter concentration was determined after drying samples at $135^{\circ} \mathrm{C}$ for $2 \mathrm{~h}$ (AOAC, 2002; method 930.15). Ash concentration was determined after $5 \mathrm{~h}$ at $550^{\circ} \mathrm{C}$ in a furnace (AOAC 2002; method 942.05). Crude protein concentration was determined according to AOAC (2000; method 990.03). 
Table 2. Ingredients and nutrient composition of experimental diets containing triticale dried distillers grains plus solubles (TDDGS), corn dried distillers grains plus solubles (CDDGS), canola meal (CM), and soybean meal (SBM)

\begin{tabular}{lcccc}
\hline Item & TDDGS & CDDGS & CM & SBM \\
\hline Feed ingredient & & & & \\
Barley silage & 34.6 & 34.6 & 34.7 & 34.7 \\
Alfalfa hay & 10.0 & 10.0 & 10.0 & 10.0 \\
Basal concentrate mix ${ }^{1}$ & 34.7 & 34.7 & 34.8 & 34.9 \\
TDDGS & 16.9 & - & - & - \\
CDDGS & - & 17.4 & - & - \\
CM & - & - & 13.0 & - \\
SBM & - & - & 7.4 & 10.2 \\
Beet pulp & 3.6 & 3.0 & 0.1 & - \\
Urea & 0.2 & 0.3 & & \\
Nutrient composition, \% of DM & & & 54.2 & 54.3 \\
DM & 54.4 & 54.4 & 90.5 & 90.6 \\
OM & 91.3 & 91.3 & 20.0 & 18.5 \\
CP & 19.2 & 19.0 & 2.5 & 2.1 \\
Ether extract & 3.3 & 3.2 & 20.5 & 20.8 \\
Starch & 21.3 & 20.8 & 36.7 & 35.5 \\
NDF & 38.2 & 38.5 & 22.3 & 22.3 \\
Forage NDF & 22.3 & 22.4 & \\
\hline
\end{tabular}

${ }^{1}$ Basal concentrate mix contained $45.4 \%$ dry ground corn, $45.4 \%$ dry rolled barley, $3.9 \%$ vitamins and trace mineral premix, $2.4 \%$ dicalcium phosphate, $2.2 \%$ limestone, and $0.7 \%$ magnesium oxide on a DM basis.

Neutral detergent fiber concentration was determined using amylase and sodium sulfite (Van Soest et al., 1991). Starch was measured by an enzymatic method (Karkalas, 1985) after samples were gelatinized with sodium hydroxide, with glucose concentration measured using a glucose oxidase/peroxidase enzyme (P7119, Sigma, St. Louis, MO) and dianisidine dihydrochloride (F5803, Sigma). Absorbance was determined at the wavelength of $450 \mathrm{~nm}$ with a plate reader (SpectraMax 190, Molecular Devices Corp., Sunnyvale, CA). Ether extract concentration was determined using a Goldfisch extraction apparatus with petroleum ether (Labconco, Kansas City, MO; Rhee, 2005). Indigestible NDF was determined as NDF residue after 120-h incubation in the rumen, and was used as an internal marker to determine apparent total-tract nutrient digestibility (Cochran et al., 1986).

Milk fat, protein, and lactose, and SCC concentrations were measured (AOAC, 1996) with infrared spectroscopy by Edmonton-Alberta DHIA (MilkoScan 605, Foss North America, Brampton, Ontario, Canada), and MUN (mg/dL) was determined with an automated infrared Fossomatic 400 Milk Analyzer (Foss North America). Milk energy output was calculated according to the NRC (2001) using measured concentrations of milk fat, protein, and lactose: $\mathrm{NE}_{\mathrm{L}}(\mathrm{Mcal} / \mathrm{kg})=0.0929$ $\times$ fat $\%+0.0547 \times \mathrm{CP} \%+0.0395 \times$ lactose $\%$. Commercial kits were used to determine plasma concentrations of insulin (Coat-A-Count, Diagnostic Products Corp., Los Angeles, CA) and NEFA (NEFA C-kit, Wako Chemicals USA, Richmond, VA). Plasma glucose concentration was measured using a glucose oxidase/ peroxidase enzyme and dianisidine dihydrochloride as described above. Plasma was also analyzed for urea nitrogen (Marsh et al., 1965) and AA concentrations (Sedgwick et al., 1991).

\section{Statistical Analysis}

Data from the in situ study were analyzed as a completely randomized design using the Mixed model procedure of SAS (version 9.1; SAS Institute Inc., Cary, NC) with the fixed effect treatment. Treatment effects were declared significant at $P<0.05$, and treatment means were separated by the Bonferroni mean separation test.

Data for the lactation study were analyzed using the Mixed model procedure of SAS according to the following model:

$$
\mathrm{Y}_{\mathrm{ijkl}}=\mu+\mathrm{C}_{\mathrm{i}}+\mathrm{P}_{\mathrm{j}}+\mathrm{T}_{\mathrm{k}}+\mathrm{e}_{\mathrm{ijkl}},
$$

where $\mu$ is the overall mean, $\mathrm{C}_{\mathrm{i}}$ is the random effect of cow ( $\mathrm{i}=1$ to 12$), \mathrm{P}_{\mathrm{j}}$ is the fixed effect of period $(\mathrm{j}$ $=1$ to 4$), \mathrm{T}_{\mathrm{k}}$ is the fixed effect of treatment $(\mathrm{k}=1$ to 4 ), and $e_{i j k l}$ is the residual, assumed to be normally distributed. Treatment effects were declared significant at $P<0.05$, and treatment means were separated by the Bonferroni mean separation test.

\section{RESULTS}

\section{In Situ Study}

The soluble protein $(\% \mathrm{CP})$ was higher $(P<0.001$; Table 3) for TDDGS and CDDGS (31.0 and 30.2\%, 
Table 3. In situ ruminal disappearance and in vitro intestinal digestibility of triticale dried distillers grains plus solubles (TDDGS), corn dried distillers grains plus solubles (CDDGS), canola meal (CM), and soybean meal (SBM)

\begin{tabular}{|c|c|c|c|c|c|c|}
\hline Item & TDDGS & CDDGS & $\mathrm{CM}$ & SBM & $\mathrm{SE}$ & $P$-value \\
\hline Soluble CP, \% of CP & $31.0^{\mathrm{a}}$ & $30.2^{\mathrm{a}}$ & $15.1^{\mathrm{b}}$ & $9.0^{\mathrm{c}}$ & 0.4 & $<0.001$ \\
\hline Rapidly degradable $\mathrm{CP},{ }^{1} \%$ of $\mathrm{CP}$ & $22.5^{\mathrm{b}}$ & $30.9^{\mathrm{a}}$ & $9.1^{\mathrm{c}}$ & $6.1^{\mathrm{c}}$ & 0.7 & $<0.001$ \\
\hline Slowly degradable $\mathrm{CP}, 2 \%$ of $\mathrm{CP}$ & $34.9^{\mathrm{c}}$ & $28.2^{\mathrm{d}}$ & $69.4^{\mathrm{b}}$ & $84.6^{\mathrm{a}}$ & 0.7 & $<0.001$ \\
\hline Rate of degradation for slowly degradable CP, \%/h & $1.80^{\mathrm{b}}$ & $1.87^{\mathrm{b}}$ & $4.10^{\mathrm{a}}$ & $4.50^{\mathrm{a}}$ & 0.2 & $<0.001$ \\
\hline Indigestible $\mathrm{CP}^{3} \%$ of $\mathrm{CP}$ & $11.7^{\mathrm{a}}$ & $10.7^{\mathrm{a}}$ & $6.4^{\mathrm{b}}$ & $0.3^{\mathrm{c}}$ & 0.7 & $<0.001$ \\
\hline $\mathrm{RDP}, \% \mathrm{CP}$ & $64.5^{\mathrm{a}}$ & $69.3^{\mathrm{a}}$ & $62.2^{\mathrm{ab}}$ & $53.0^{\mathrm{b}}$ & 2.0 & $<0.001$ \\
\hline In vitro intestinal digestibility, $\%$ of $\mathrm{CP}$ & $14.0^{\mathrm{bc}}$ & $8.5^{\mathrm{c}}$ & $18.4^{\mathrm{b}}$ & $33.9^{\mathrm{a}}$ & 1.2 & $<0.001$ \\
\hline In vitro intestinal digestibility, \% of RUP & 39.4 & 27.7 & 48.7 & 72.1 & $\mathrm{ND}^{4}$ & ND \\
\hline Expected total-tract digestibility, \% of CP & $78.5^{\mathrm{b}}$ & $77.8^{\mathrm{b}}$ & $80.7^{\mathrm{b}}$ & $86.8^{\mathrm{a}}$ & 1.2 & $<0.001$ \\
\hline
\end{tabular}

${ }^{\mathrm{a}-\mathrm{d}}$ Treatment means within a row with different superscripts were significantly different $(P<0.05)$.

${ }^{1}$ Defined as CP disappeared within $1 \mathrm{~h}$ of ruminal incubation.

${ }^{2}$ Calculated by subtracting soluble $\mathrm{CP}$, rapidly degradable $\mathrm{CP}$, and indigestible $\mathrm{CP}$ from 100 .

${ }^{3}$ Defined as $\mathrm{CP}$ residues after $72 \mathrm{~h}$ of ruminal incubation.

${ }^{4}$ Not determined, because animals were not experimental units.

respectively) compared with $\mathrm{CM}(15.1 \%)$ and SBM (9.0\%). The rapidly degradable protein $(\% \mathrm{CP})$ was highest $(P<0.001)$ for CDDGS $(30.9 \%)$ followed by TDDGS (22.5\%), CM (9.1\%), and SBM (6.1\%). Slowly degradable protein concentration was highest for SBM, intermediate for CM, and lowest for TDDGS and CDDGS. Degradation rate of slowly degradable protein was faster $(P<0.001)$ for SBM and CM $(4.50$ and $4.10 \% / \mathrm{h}$, respectively) than for CDDGS and TDDGS (1.87 and $1.80 \% / \mathrm{h}$, respectively). Rumen degradable protein after $16 \mathrm{~h}$ of incubation was higher $(P<0.001)$ for CDDGS and TDDGS (69.3 and $64.5 \%$, respectively) than CM $(62.2 \%)$ and SBM $(53.0 \%)$. However, in vitro intestinal digestibility $(\% \mathrm{CP})$ was highest $(P<0.001)$ for SBM (33.9\%), followed by CM (18.4\%), TDDGS (14.0\%), and CDDGS (8.5\%). As a result, the estimated totaltract digestibility of $\mathrm{CP}$ was higher for SBM (86.8\%) compared with CM, TDDGS, and CDDGS (80.7, 78.5, and $77.8 \%$, respectively).

\section{Animal Study}

Dry matter intake did not differ among treatments and averaged $25.5 \mathrm{~kg} / \mathrm{d}$ (Table 4). Apparent total-tract digestibility of DM was lower $(P=0.01)$ for cows fed CDDGS than for those fed SBM, and that of OM was lower $(P<0.01)$ for cows fed CDDGS or TDDGS compared with those fed SBM. Apparent total-tract digestibility of $\mathrm{CP}$ was lower $(P=0.04)$ for cows fed CDDGS compared with those fed CM, but the CP digestibility for TDDGS did not differ from that of the other treatments. Starch and NDF digestibility did not differ among treatments. Treatment did not affect OM apparently digested in the total tract, either.

Plasma concentrations of glucose, urea $\mathrm{N}$, and insulin did not differ among treatments (Table 5). Plasma Arg concentration was lower for cows fed CDDGS than for those fed CM or SBM. Plasma concentrations of Lys, Thr, and Ile were lower $(P<0.01)$ for cows fed TDDGS or CDDGS than for cows fed CM or SBM. Further, cows fed CDDGS had lower plasma concentrations of Ile and Trp than cows fed CM $(P \leq 0.01)$. Plasma Leu concentration was higher $(P<0.001)$ for cows fed TDDGS or CDDGS than for cows fed CM or SBM. The concentrations of His, Val, Met, Phe, and total essential AA did not differ among treatments. The concentrations for the majority of nonessential AA were not affected by treatment. However, the concentration of Asn

Table 4. Dry matter intake and nutrient digestibility of lactating dairy cows fed triticale dried distillers grains plus solubles (TDDGS), corn dried distillers grains plus solubles (CDDGS), canola meal (CM), or soybean meal (SBM)

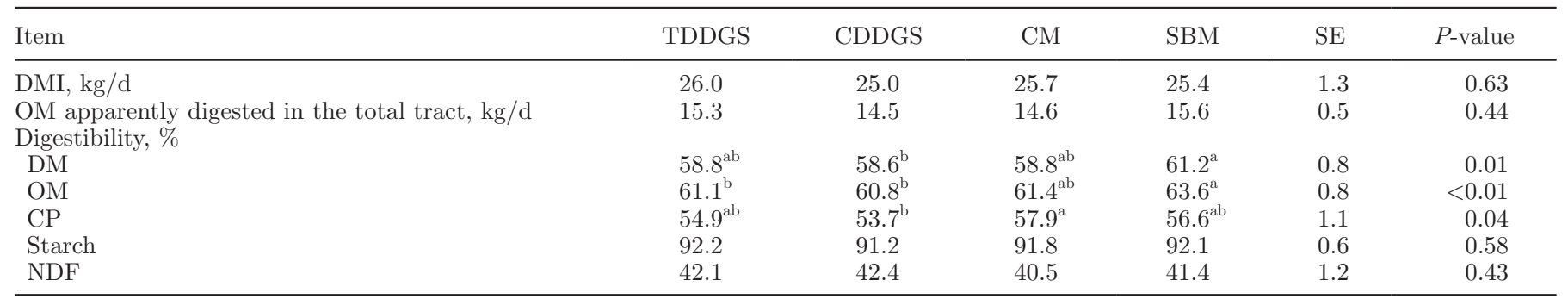

\footnotetext{
${ }^{\mathrm{a}, \mathrm{b}}$ Treatment means within a row with different superscripts were significantly different $(P<0.05)$.
} 
Table 5. Plasma metabolites of lactating dairy cows fed triticale dried distillers grains plus solubles (TDDGS), corn dried distillers grains plus solubles (CDDGS), canola meal (CM), or soybean meal (SBM)

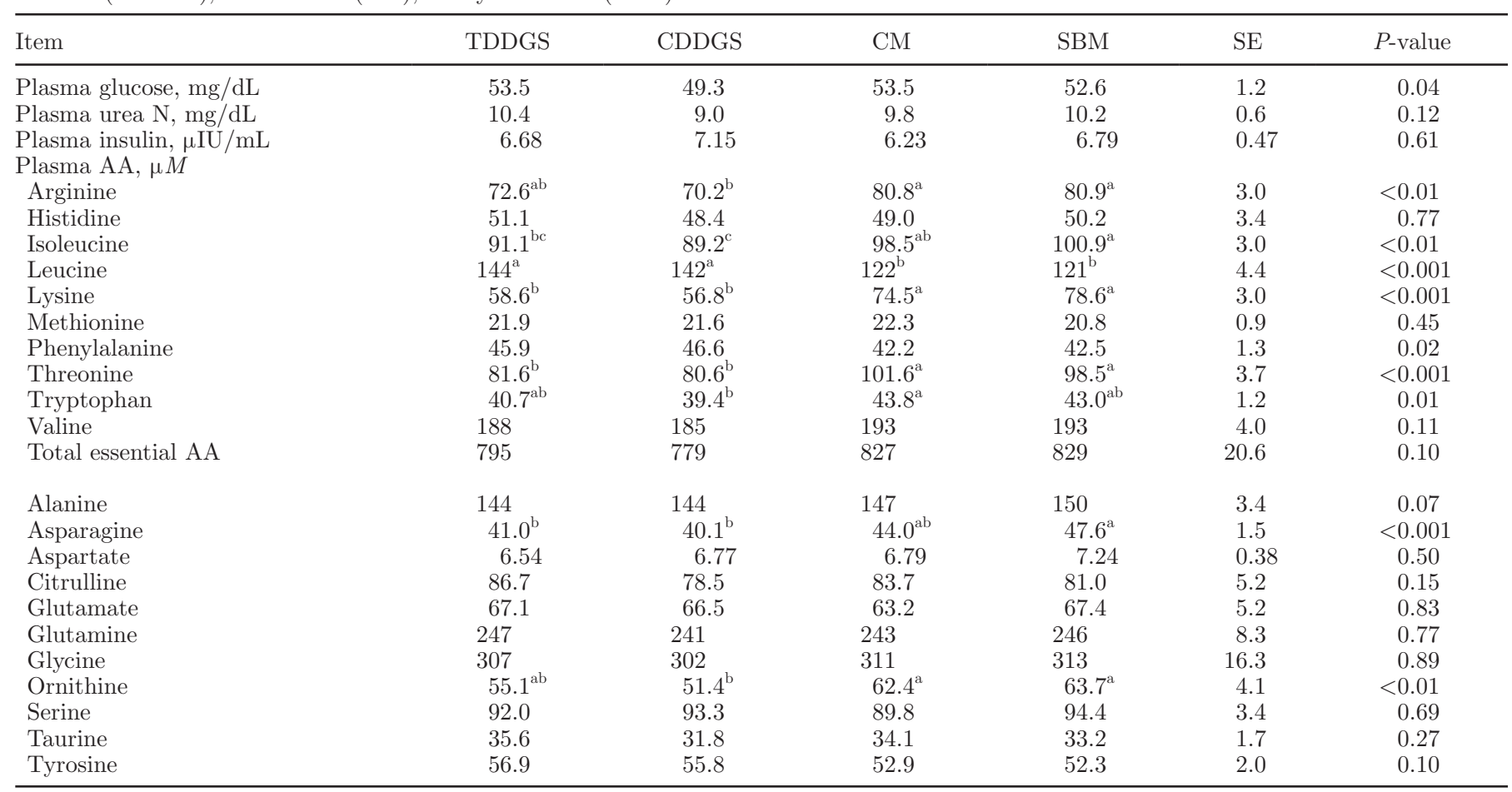

${ }^{\mathrm{a}, \mathrm{b}}$ Treatment means within a row with different superscripts were significantly different $(P<0.05)$.

was lower for cows fed TDDGS or CDDGS $(P<0.001)$ than for those fed SBM. Additionally, the concentration of ornithine was lower $(P<0.01)$ for cows fed CDDGS than those for fed CM or SBM.

Dietary treatment did not affect the yield of milk, $4 \%$ FCM, milk lactose, or milk fat (Table 6). However, cows fed CDDGS $(1.07 \mathrm{~kg} / \mathrm{d})$ had lower $(P=0.03)$ milk CP yield than cows fed CM $(1.16 \mathrm{~kg} / \mathrm{d})$; cows fed TDDGS and SBM had an intermediate milk CP yield $(1.12$ and $1.15 \mathrm{~kg} / \mathrm{d})$. Milk protein concentration was lower for $(P<0.01)$ for cows fed TDDGS or CDDGS compared with those fed SBM (3.16 and 3.12 vs. $3.25 \%$, respectively), and MUN concentration was lower $(P=$ 0.01) for CDDGS compared with CM or SBM treatment (12.3 vs. 14.1 and $14.3 \mathrm{mg} / \mathrm{dL}$, respectively). The concentrations of milk fat and lactose did not differ among treatments. Furthermore, SCC did not differ among treatments.

Although overall $P$-values were $\leq 0.05$ for plasma concentrations of glucose and Phe and BW change, treatment means did not differ according to the Bonferroni mean separation test.

\section{DISCUSSION}

In this study, experimental diets were formulated to supply $30 \%$ of dietary CP from TDDGS, CDDGS, CM, or SBM to evaluate effects of primary dietary protein source on animal responses. Milk protein yield was lower for cows fed CDDGS compared with those fed CM, but not for cows fed TDDGS. Although CP concentrations of experimental diets were relatively high, ranging from 18.5 to $20.0 \%$, the treatment effect on milk protein yield suggests that the MP supply, AA profile of MP, or both possibly limited milk protein production. Feed samples collected during the animal study revealed that the dietary $\mathrm{CP}$ concentration was slightly higher for the $\mathrm{CM}$ treatment. However, dietary CP concentration was similar for TDDGS, CDDGS, and SBM treatments, indicating that lower milk protein yield for CDDGS relative to $\mathrm{CM}$ treatment cannot be attributed solely to differences in dietary CP supply.

Previous research showed that replacing SBM with CDDGS results in variable animal responses. Cows fed CDDGS as the primary dietary protein source often increase milk yield, milk protein yield, or milk protein concentration (Powers et al., 1995; Anderson et al., 2006; Kleinschmit et al., 2006). However, feeding CDDGS sometimes reduced milk production (Palmquist and Conrad, 1982; Van Horn et al., 1985; Owens and Larson, 1991). Lower milk production for cows fed CDDGS was attributed to low availability of protein because of extensive heat damage (Van Horn et al., 1985 ) or to poor amino acid profile (Palmquist and 
Table 6. Productivity of lactating dairy cows fed triticale dried distillers grains plus solubles (TDDGS), corn dried distillers grains plus solubles (CDDGS), canola meal (CM), or soybean meal (SBM)

\begin{tabular}{|c|c|c|c|c|c|c|}
\hline Item & TDDGS & CDDGS & $\mathrm{CM}$ & SBM & $\mathrm{SE}$ & $P$-value \\
\hline \multicolumn{7}{|l|}{ Yield, $\mathrm{kg} / \mathrm{d}$} \\
\hline Milk & 35.9 & 34.5 & 36.2 & 35.4 & 0.7 & 0.34 \\
\hline $4 \% \mathrm{FCM}$ & 32.1 & 32.2 & 33.1 & 32.0 & 1.7 & 0.62 \\
\hline Milk protein & $1.12^{\mathrm{ab}}$ & $1.07^{\mathrm{b}}$ & $1.16^{\mathrm{a}}$ & $1.15^{\mathrm{ab}}$ & 0.05 & 0.03 \\
\hline Milk lactose & 1.63 & 1.54 & 1.62 & 1.58 & 0.11 & 0.27 \\
\hline \multicolumn{7}{|l|}{ Concentration } \\
\hline Milk lactose, \% & 4.46 & 4.42 & 4.38 & 4.40 & 0.05 & 0.19 \\
\hline SCC. $10^{3} / \mathrm{mL}$ & 114 & 198 & 189 & 85 & 72 & 0.35 \\
\hline MUN, mg/dL & $13.4^{\mathrm{ab}}$ & $12.3^{\mathrm{b}}$ & $14.1^{\mathrm{a}}$ & $14.3^{\mathrm{a}}$ & 0.8 & 0.01 \\
\hline Milk N/N intake & 0.22 & 0.22 & 0.23 & 0.24 & 0.01 & 0.45 \\
\hline $\mathrm{NE}_{\mathrm{L}}$ in milk, Mcal/d & 23.3 & 23.2 & 23.8 & 23.3 & 1.4 & 0.77 \\
\hline BW change, g/d & 514 & -290 & -110 & 390 & 229 & 0.05 \\
\hline BCS change, $/ 21 \mathrm{~d}$ & -0.08 & 0.13 & 0 & 0 & 0.09 & 0.50 \\
\hline
\end{tabular}

${ }^{\mathrm{a}, \mathrm{b}}$ Treatment means within a row with different superscripts were significantly different $(P<0.05)$.

Conrad, 1982). Inconsistent data in literature are likely due to variable feeds and their quality that DDGS replaced in each study, but could be also attributed to variable quality of DDGS used across many studies. The ADIN concentration of feeds is a useful indicator of nonusable N (NRC, 2001), and DDGS greatly varies in ADIN concentration among sources (Kleinschmit et al., 2007a). Cows fed CDDGS with lower ADIN concentration increased milk protein concentration compared with those fed CDDGS with higher ADIN concentration (Powers et al., 1995; Kleinschmit et al., 2006), indicating that ADIN concentration of DDGS can affect animal responses to DDGS.

\section{MP Supply}

In vitro intestinal digestibility of CDDGS used in the present study was very low relative to the values reported by Kleinschmit et al. (2007a). Metabolizable protein consists of microbial, ruminally undegradable, and endogenous true proteins that are digested in the small intestine (NRC, 2001), but less RUP digested in the small intestine might be the most probable reason to explain the lower milk protein yield observed for cows fed CDDGS compared with those fed CM. It is generally accepted that DDGS have less RDP compared with CM and SBM (Firkins et al., 1984; NRC, 2001). However, in situ data showed that TDDGS and CDDGS used in this study had greater soluble CP and rapidly degradable $\mathrm{CP}$ fractions compared with $\mathrm{CM}$ and SBM. In addition, more urea was added to the diets containing TDDGS and CDDGS to ensure that diets were isonitrogenous. As a result, the RDP concentration of TDDGS and CDDGS diets increased further, decreasing their RUP concentration. However, in spite of greater $\mathrm{CP}$ degradability in the rumen, in vitro intestinal $\mathrm{CP}$ digestibility was lower for CDDGS compared with $\mathrm{CM}$, and consistent with this finding, apparent total-tract digestibility of $\mathrm{CP}$ was lower for cows fed CDDGS compared with those fed CM. However, TDDGS and CM treatments had similar in vitro intestinal CP digestibility, and apparent total-tract CP digestibility for TDDGS treatment did not differ from that of the other treatment. These observations indicated that the CDDGS, but not the TDDGS, might not have provided sufficient MP from RUP compared with $\mathrm{CM}$ and SBM treatments.

In a previous study, Greter et al. (2008) compared TDDGS and CDDGS that were from the same lots as the current study. They reported that cows fed CDDGS had higher concentrations of plasma AA and MUN compared with those fed TDDGS, indicating the possibility of greater absorption of MP for cows fed CDDGS. However, plasma concentrations of AA were not affected by type of DDGS in the current study. This discrepancy might be related to differences in fermentability of experimental diets between the 2 studies. Diets used in the previous study might have greater ruminal fermentation because dry rolled barley grain was used as the primary source of dietary starch, whereas the current study used a 50:50 mixture of dry ground corn and dry rolled barley grain. Overton et al. (1995) reported that rolled barley grain increases ruminal starch digestibility compared with dry ground corn. Thus, if CDDGS provides more readily available RDP than TDDGS, as indicated by the in situ data from the current study, experimental diets in the previous study might be more efficient in capturing RDP for microbial protein synthesis, providing more MP from microbial protein, and increasing concentrations of plasma essen- 
tial AA. However, the greater concentration of plasma essential AA did not increase milk protein yield in the previous study, but did increase MUN, possibly because MP supply did not limit milk protein production in the previous study. Contrarily, in the current study, the CDDGS treatment did not increase concentrations of plasma essential AA or MUN, indicating that feeding CDDGS did not increase MP supply. However, it is not possible to confirm these speculations because microbial protein production was not measured in either study.

\section{AA Profile}

The CDDGS used in the current study had a lower Lys concentration (both \% CP and \% RUP) compared with the other protein feeds, which also may explain the lower milk protein yield compared with CM treatment. Previous research showed that animal responses to CDDGS were affected by other diet ingredients that optimize amino acid profile of MP. For example, cows fed CDDGS increased milk protein yield compared with those fed SBM to a greater extent when ruminally protected Lys and Met were supplemented (Nichols et al., 1998) or when diets contained blood meal (Powers et al., 1995). Furthermore, Kleinschmit et al. (2007b) reported that cows fed CDDGS at $15 \%$ of dietary DM increased milk yield when alfalfa hay replaced corn silage. In the current study, alfalfa hay was fed at only $10 \%$ of dietary DM, and protein supplements that are high in Lys concentration were not included in the experimental diets. Therefore, availability of Lys likely limited milk protein production in the CDDGS diet.

Concentrations of Arg, Ile, Lys, and Thr in RUP were lower for TDDGS and CDDGS than for CM and SBM, which was reflected in the treatment effect on plasma AA concentration; plasma concentrations of Ile, Lys, and Thr were lower for cows fed CDDGS than for those fed CM and SBM. These observations confirmed the findings of Kleinschmit et al. (2006), who reported that feeding DDGS decreased concentration of arterial plasma concentrations of Arg, Ile, Lys, and Thr. However, cows in the TDDGS treatment did not have significantly lower plasma concentrations of Arg and Trp compared with the other treatments, whereas cows fed CDDGS had a lower Arg concentration compared with those fed CM and SBM, and a lower Trp concentration compared with those fed CM. These findings are consistent with the data on milk protein yield, in which cows fed CDDGS had decreased milk protein yield compared with those fed CM or SBM, but the difference between TDDGS and the other treatments was not significant.

\section{Variation in RDP}

The TDDGS and CDDGS used in this study had RUP values of 35.5 and $30.7 \%$, respectively (64.5 and $69.3 \%$ RDP with 16 -h ruminal incubation). A study by Kononoff et al. (2007) reported that the RUP of DDGS varied from 39.1 to $46.8 \%$ when measured after a $16-\mathrm{h}$ ruminal incubation. Powers et al. (1995) evaluated CDDGS from 3 sources and reported RUP values of 43.7 to $46.5 \%$, assuming the passage rate of $5.0 \% / \mathrm{h}$. However, Kleinschmit et al. (2007a) reported RUP values ranged from 59.1 to $71.7 \%$ for DDGS from 5 sources, assuming the passage rate of $6.8 \% / \mathrm{h}$. These discrepancies are caused in part by the different methods to estimate RUP values of feeds, but variation in the extent of actual protein degradation in the rumen may exist among different sources of DDGS.

The soluble CP fraction of DDGS is also extremely variable in the literature. For the current study, the soluble CP fraction was 31.0 and $30.2 \%$ for TDDGS and CDDGS, respectively. In the literature, soluble CP fractions of DDGS were 26.1 to $31.2 \%$ (Powers et al., 1995 ) and 13.4 to $19.7 \%$ (Kleinschmit et al., 2007a). In the current study, we found that an additional 22.5 and $30.9 \%$ of $\mathrm{CP}$ were degraded within $1 \mathrm{~h}$ of ruminal incubation for TDDGS and CDDGS, respectively. Sasikala-Appukuttan et al. (2008) reported that feeding condensed corn distillers solubles increases ruminal ammonia concentration. Although DDGS is considered a high-RUP feed, the RUP content of DDGS can vary greatly depending on the amount of solubles added back to the dried distillers grains. However, extensive DM particulate loss from the nylon bags might be another possible explanation for low RUP values for the TDDGS and CDDGS used in the present study.

\section{CONCLUSIONS}

Cows fed CDDGS had decreased milk CP yield compared with those fed CM, which can be partially attributed to poor AA profile and lower intestinal digestibility of RUP for CDDGS. However, cows fed TDDGS maintained similar milk production to that of cows fed CM or SBM. These data suggest that TDDGS can replace CM or SBM in the diets of lactating dairy cows without adverse effects on production. Furthermore, although DDGS have been generally accepted as a feed that is high in RUP, in situ ruminal degradability was high for CDDGS and TDDGS in the present study. Further investigation is warranted to determine the extent of variations in ruminal protein degradation among different type and source of DDGS. 


\section{ACKNOWLEDGMENTS}

The authors of this study gratefully acknowledge V. S. Heron, L. Kutryk, and C. Owen (University of Alberta, Edmonton, Alberta, Canada) for technical assistance. We thank the Dairy Research and Technology Center staff for general animal care. Financial support from the Alberta Agriculture Research Institute (Edmonton, Alberta, Canada) and Alberta Milk (Edmonton, Alberta, Canada) is gratefully acknowledged.

\section{REFERENCES}

Anderson, J. L., D. J. Schingoethe, K. F. Kalscheur, and A. R. Hippen 2006. Evaluation of dried and wet distillers grains included at two concentrations in the diets of lactating dairy cows. J. Dairy Sci. 89:3133-3142.

AOAC. 1996. Official Methods of Analysis. 16th ed. Assoc. Off. Anal. Chem., Gaithersburg, MD.

AOAC. 2000. Official Methods of Analysis. 17th ed. Assoc. Off. Anal. Chem., Arlington, VA.

AOAC. 2002. Official Methods of Analysis. 17th ed. Rev. 1. Assoc. Off. Anal. Chem., Arlington, VA.

Calsamiglia, S., and M. D. Stern. 1995. A three-step in vitro procedure for estimating intestinal digestion of protein in ruminants. J. Anim. Sci. 73:1459-1465.

Canadian Council on Animal Care. 1993. Guide to the Care and Use of Experimental Animals. Vol. 1. E. D. Olfert, B. M. Cross, and A. A. McWilliam, ed. CCAC, Ottawa, Ontario, Canada.

Clark, P. W., and L. E. Armentano. 1997. Replacement of alfalfa neutral detergent fiber with a combination of nonforage fiber sources. J. Dairy Sci. 80:675-680.

Cochran, R. C., D. C. Adams, J. D. Wallace, and M. L. Galyean. 1986. Predicting digestibility of different diets with internal markers: Evaluation of four potential markers. J. Anim. Sci. 63:14761483.

Firkins, J. L., L. L. Berger, G. C. Fahey Jr., and N. R. Merchen. 1984. Ruminal nitrogen degradability and escape of wet and dry distillers grains and wet and dry corn gluten feeds. J. Dairy Sci. 67:1936-1944.

Greter, A. M., G. B. Penner, E. C. Davis, and M. Oba. 2008. Effects of replacing corn dry distillers' grains with triticale dry distillers' grains on lactation performance and plasma metabolites of dairy cows. Can. J. Anim. Sci. 88:129-132.

Karkalas, J. 1985. An improved enzymatic method for the determination of native and modified starch. J. Sci. Food Agric. 36:1019-1027.

Kim, B. G., M. D. Lindemann, M. Rademacher, J. J. Brennan, and G. L. Cromwell. 2006. Efficacy of DL-methionine hydroxy analog free acid and DL-methionine as methionine sources for pigs. J. Anim. Sci. 84:104-111.

Kleinschmit, D. H., J. L. Anderson, D. J. Schingoethe, K. F. Kalschuer, and A. R. Hippen. 2007a. Ruminal and intestinal degradability of distillers grains plus soluble varies by source. J. Dairy Sci. 90:2909-2918.

Kleinschmit, D. H., D. J. Schingoethe, A. R. Hippen, and K. F. Kalschuer. 2007b. Dried distillers grains plus solubles with corn silage or alfalfa hay as the primary forage source in dairy cow diets. J. Dairy Sci. 90:5587-5599.

Kleinschmit, D. H., D. J. Schingoethe, K. F. Kalscheur, and A. R. Hippen. 2006. Evaluation of various sources of corn distillers dried grains plus solubles for lactating dairy cattle. J. Dairy Sci. 89:4784-4794.

Kononoff, P. J., S. K. Ivan, and T. J. Klopfenstein. 2007. Estimation of the proportion of feed protein digested in the small intestine of cattle consuming wet corn gluten feed. J. Dairy Sci. 90:23772385.

Leonardi, C., S. Bertics, and L. E. Armentano. 2005. Effect of increasing oil from distillers grains or corn oil on lactation performance. J. Dairy Sci. 88:2820-2827.

Marsh, W. H., B. Fingerhut, and E. Kirsch. 1965. Automated and manual direct methods for the determination of blood urea. Clin. Chem. 11:624-627.

Mead, R., R. N. Curnow, and A. M. Hasted. 2003. Statistical Methods in Agriculture and Experimental Biology. 3rd ed. CRC Press LLC, Boca Raton, FL.

Mustafa, A. F., J. J. McKinnon, M. W. Ingledew, and D. A. Christensen. 2000. The nutritive value for ruminants of thin stillage and distillers' grains derived from wheat, rye, triticale and barley. J. Sci. Food Agric. 80:607-613.

Nichols, J. R., D. J. Schingoethe, H. A. Maiga, M. J. Brouk, and M. S. Piepenbrink. 1998. Evaluation of corn distillers grains and ruminally protected lysine and methionine for lactating dairy cows. J. Dairy Sci. 81:482-491.

NRC. 2001. Nutrient Requirements of Dairy Cattle. 7th ed. National Academy Press, Washington, DC.

Overton, T. R., M. R. Cameron, J. P. Elliott, J. H. Clark, and D. R. Nelson. 1995. Ruminal fermentation and passage of nutrients to the duodenum of lactating cows fed mixtures of corn and barley. J. Dairy Sci. 78:1981-1998.

Owens, F. G., and L. L. Larson. 1991. Corn distillers dried grains versus soybean meal in lactation diets. J. Dairy Sci. 74:972-979.

Palmquist, D. L., and H. R. Conrad. 1982. Utilization of distillers dried grains plus solubles by dairy cows in early lactation. J. Dairy Sci. 65:1729-1733.

Powers, W. J., H. H. Van Horn, B. Harris Jr., and C. J. Wilcox. 1995. Effects of variable sources of distillers dried grains plus solubles on milk yield and composition. J. Dairy Sci. 78:388-396.

Rhee, K. C. 2005. Determination of total nitrogen. Pages 105-113 in Handbook of Food Analytical Chemistry: Water, Proteins, Enzymes, Lipids, and Carbohydrates. R. E. Wrolstad, E. A Decker, S. J. Schwartz, and P. Sporns, ed. John Wiley and Sons, Hoboken, NJ.

Sasikala-Appukuttan, A. K., D. J. Schingoethe, A. R. Hippen, K. F. Kalscheur, K. Karges, and M. L. Gibson. 2008. The feeding value of corn distillers solubles for lactating dairy cows. J. Dairy Sci. 91:279-287.

Sedgwick, G. W., T. F. Fenton, and J. R. Thompson. 1991. Effect of protein precipitating agents on the recovery of plasma free amino acids. Can. J. Anim. Sci. 71:953-957.

Van Horn, H. H., O. Blanco, B. Harris Jr., and D. K. Beede. 1985. Interaction of protein percent with caloric density and protein source for lactating cows. J. Dairy Sci. 68:1682-1695.

Van Soest, P. J., J. B. Robertson, and B. A. Lewis. 1991. Methods for dietary fiber, neutral detergent fiber and non-starch polysaccharide in relation to animal nutrition. J. Dairy Sci. 74:3583-3597.

Wang, S., K. C. Thomas, W. M. Ingledew, K. Sosulski, and F. W. Sosulski. 1997. Rye and triticale as feedstock for fuel ethanol production. Cereal Chem. 74:621-625.

Wildman, E. E., G. M. Jones, P. E. Wagner, R. L. Boman, H. F. Trout Jr., and T. N. Lesch. 1982. A dairy cow body condition scoring system and its relationship to selected production characteristics. J. Dairy Sci. 65:495-501. 